\title{
СПЕЦИФИЧНОСТЬ ОТНОШЕНИЙ ЧАСТНОЙ СОБСТВЕННОСТИ В РОССИИ
}

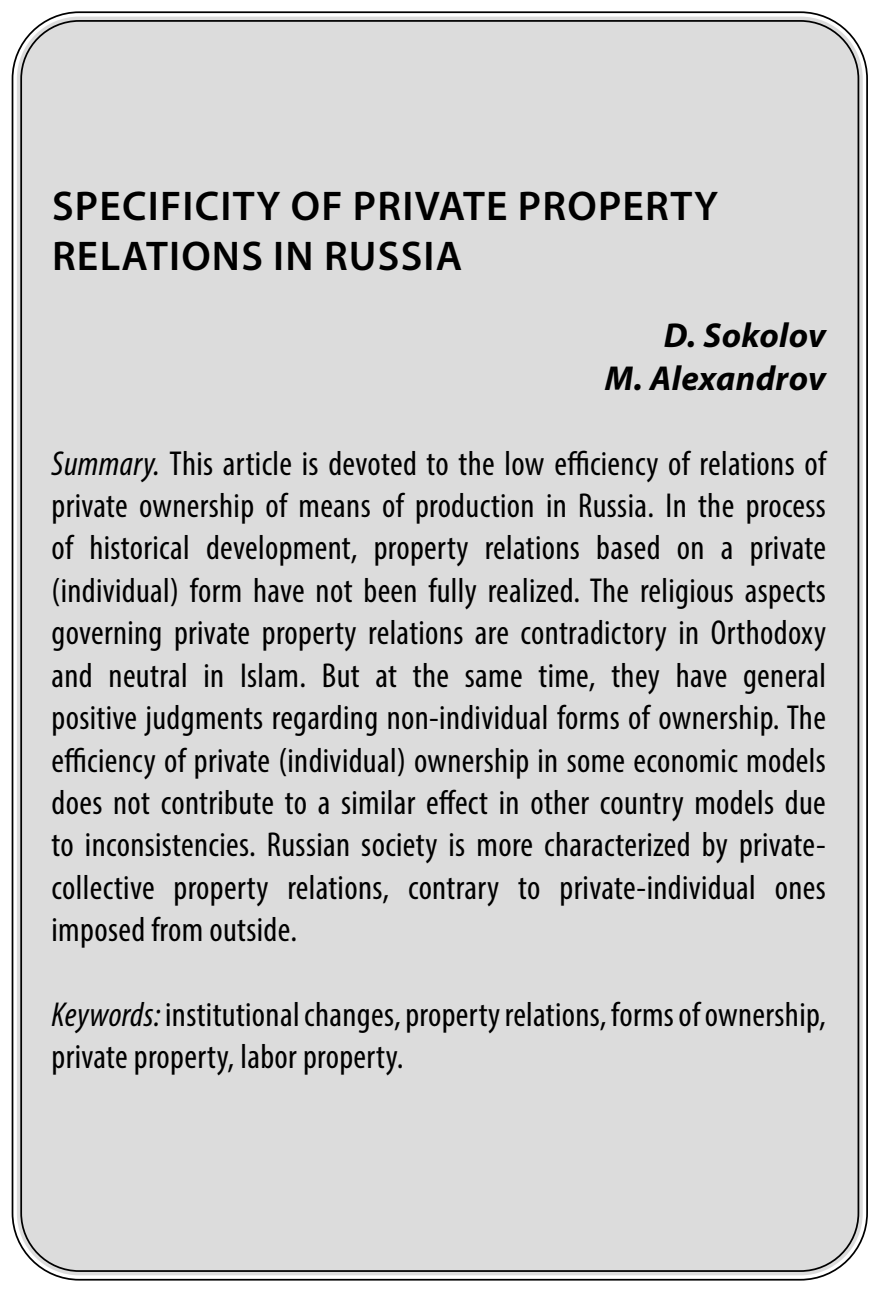

O сновой существования любой экономической системы являются отношения собственности, а основой эффективного функционирования национальной модели экономической системы - специфика отношений собственности. Становление и развитие современных моделей экономических систем осуществлялось по двум направлениям. Одна группа стран переходила от чистого капитализма к современной рыночной экономике эволюционным путем (США, Канада, ФРГ, Франция, Италия, Испания и др.). Другая группа - (Россия, Польша, Чехия, Болгария и другие государства бывшего «соцлагеря») до перехода к современной рыночной экономики развивалась продолжительный период времени в условиях командно-административных отношений. Спецификой эволюционного развития является формирование отношений собственности с учетом национальных осо-
Соколов Дмитрий Викторович

К.э.н., дочент, ФГБОУВО «Чувашский государственный университет имени И.Н. Ульянова»,

2. Чебоксары

sokolov77@inbox.ru

Александров Михаил Вячеславович К.э.н., доцент, ФГБОУ ВО «Чувашский государственный университет имени И.Н. Ульянова»,

2. Чебоксары

amv-ekf@yandex.ru

Аннотация. Данная статья посвящена низкой эффективности отношений частной собственности на средства производства в России. В процессе исторического развития отношения собственности, основанные на частной (индивидуальной) форме, не были реализованы в полном объеме. Религиозные аспекты, регламентирующие отношения частной собственности, носят противоречивый характер в православии и нейтральный - в исламе. Но при этом имеют общие положительные суждения в отношении не индивидуальных форм собственности. Эффективность частной (индивидуальной) собственности в одних экономических моделях не способствует достижению аналогичного эффекта в моделях других стран по причине рассогласованности. Российскому социуму в большей степени свойственны частно-коллективные отношения собственности вопреки навязанным извне частно-индивидуальным.

Ключевые слова: институциональные изменения, отношения собственности, формы собственности, частная собственность, трудовая собственHость.

бенностей, реформаторский путь предполагает трансформацию отношений собственности, ориентируясь на уже существующие образцы, доказавшие свою эффективность.

Не повергается сомнению, что современная рыночная экономика основана на многообразии форм собственности. Но эффективность функционирования многообразия форм и видов собственности определяется специфичностью соответствующих ей отношений. Становление и развитие рыночной экономики опирается на частную собственность, которая в течение трех десятилетий не обеспечила экономике России должного развития.

Национальная специфичность отношений собственности формируется на основе множественных критери- 
ев, среди наиболее важных нами выделены следующие: историческое развитие, религиозные позиции, место личности в социуме.

Специфичность национальных отношений собственности формируется в процессе исторического развития. С отменой крепостного права в России начинают формироваться постфеодальные отношения собственности. «Субъектом земельных правоотношений стала признаваться крестьянская земельная община, увеличилось число собственников-крестьян» [3, С. 83]. Но реформа П.А. Столыпина не была доведена до логического завершения. «Реформа не успела создать развитого слоя мелких частных собственников в России до революции 1917 г» [1, С. 199]. Таким образом, полноценные отношения собственности на основе мелких частных (индивидуальных) собственников не были сформированы.

Следующим этапом развития отношений собственности в России принято считать новую экономическую политику (НЭП). Период НЭПа характеризуется многообразным функционированием государственной и частной форм собственности. При этом приоритетными являлись частно-коллективные отношения собственности, которые приняли форму кооперативов, артелей и акционерных обществ с распределением значительной части прибыли в пользу рабочих. Дальнейшее функционирование отношений собственности до распада Советского Союза основывалось на исключении частной формы собственности на средства производства.

Таким образом, полноценные отношения собственности на основе частной формы в России, в процессе исторического развития не были реализованы.

Религиозные аспекты отношений собственности определяются двумя наиболее распространенными религиями России - православием и исламом.

Отправной точкой в христианстве является отношение к объектам собственности как к принадлежащим Богу. Все, чем владеет человек, он получил от Бога; это воззрение главенствующее и неоспоримое. Ничто внешнее не бывает абсолютной собственностью: «человек является лишь временным собственником» [6, С. 162]. Из чего следует, что существование частной собственности противоречит православным канонам, но в тоже время не отрицается по ряду косвенных аргументов. Без имущества человек не может заниматься благотворительностью и не будет иметь средств к существованию [4, С. 106]. Еще одним аргументом, не противоречащим частной собственности, является ее защита от различных посягательств (от желания чужого имущества до кражи). Украденное имущество должно быть возвращено владельцу, а укравший - наказан [6, С. 164]. В противовес частной главенствующей в христианстве признается общая собственность.

Неоднозначность взгляда на частную собственность объясняется отсутствием в православии права собственности. Поэтому единым владельцем всего признается только Бог, а человеку дается право распоряжаться «по воле Бога». Поэтому человек в соответствии с православными канонами может распоряжаться имуществом и приумножать его, участвовать в благотворительности и нести государственную повинность.

В исламе отношения собственности изложены с менее абстрактной позиции. Имущество может находиться в частной, коллективной, государственной, общей и иных формах собственности. Частная (индивидуальная) собственность не осуждается и не ограничивается подобно православным традициям. Но в тоже время по законам Шариата частное имущество может изыматься в пользу государства с целью удовлетворения общественных потребностей.

Целью имущества, находящегося в частной собственности, является удовлетворение собственных потребностей и благотворительность. Право частной собственности защищается по мусульманским обычаям отсечением руки. За посягательство на иную собственность предусматриваются менее жесткие наказания. Эффективности частной собственности также придается особое значение. Не используемая в течение нескольких лет земля может передаться другому частному собственнику, способному ее возделывать [7].

Шариат признает различные способы приобретения права частной собственности, но приоритет отдается собственному труду и коммерческой деятельности. Однако некоторые виды деятельности находятся под запретом (ростовщичество, азартные игры, рисковые обязательства).

Несмотря на приоритет частной собственности перед другими формами, в тоже время существуют ограничения для нахождения имущества в частной собственности, которое должно быть в свободном доступе (дороги, мечети, реки и т.д.). Согласно Корану в совместном пользовании людей находятся три вещи: пастбища, вода и огонь [7]. Поэтому такие объекты должны находиться в коллективной, государственной или общей собственности.

Таким образом, специфика отношений собственности в христианстве входит в противоречие с частной (индивидуальной) формой, а отношения собственности в исламе занимают нейтральную позицию. 
Таблица. 1. «Индивидуализм - коллективизм» в отношениях собственности

\begin{tabular}{|l|l|l|}
\hline Критерии & Индивидуализм & Коллективизм \\
\hline Приоритетная цель & Личная & Общественная (групповая) \\
\hline Социальная структура общества & $\begin{array}{l}\text { Свободная (каждый заботится только } \\
\text { о себе) }\end{array}$ & $\begin{array}{l}\text { Строгая (группы в которыху каждого своя } \\
\text { роль) }\end{array}$ \\
\hline Принятие управленческих решений & Индивидуально & Коллективно \\
\hline Ответственность за принятые решения & Личная & Коллегиальная \\
\hline Доминирующая форма собственности & Частная (индивидуальная) & Частная (коллективная) \\
\hline
\end{tabular}

Низкую эффективность реализации частной собственности в России можно обосновать институциональными изменениями, основанными на импорте институтов. Так в России при проведении реформ в начале 90-х годов прошлого века за образец была взята американская экономическая модель, с ее структурой и спецификой отношений собственности.

В соответствии с теорией культурных изменений Г. Хофстеде попытка использовать в качестве образца для России американскую экономическую модель изначально была обречена на провал. Причина рассогласованности американской и российской экономических моделей объясняется различным положением человека в обществе. Согласно второму параметру методики Хофстеде «индивидуализм - коллективизм» РФ и США характеризуются разнополярными культурами. Американская культура основана на индивидуализме, в то время как российской присущи коллективные черты [5, С. 51]. Используя методику Хофстеде, выделим различия данных культур в отношениях частной собственности (таблица 1.).
Из возможных характеристик, оказывающих непосредственное влияние на отношения собственности, индивидуализму присуща частно-индивидуальная форма собственности, а коллективизму - частно-коллективная. Соответственно, невозможно воспроизвести отношения собственности, доказавшие свою результативность в одном социуме с той же степенью эффективности в противоположенном социуме.

Таким образом, низкая результативность функционирования частной формы собственности в России объясняется следующими критериями:

- отсутствием опыта реализации отношений собственности в процессе исторического развития;

- отрицательное отношение православия и нейтральное отношение ислама к индивидуальной частной собственности;

- отрицание российским социумом частно-индивидуальных отношений собственности на средства производства, который больше тяготеет к частно-коллективным отношениям.

\section{ЛИТЕРАТУРА}

1. Алейников Б. История возникновения и развития собственности в России: от общинной собственности к усилению роли частной собственности / Б. Алейников // Экономика и право. — 2014. — № 4. - С. 196-202.

2. Коваль Т.Б. Личность и собственность. Христианство и другие религии мира / Т.Б. Коваль // Мир России. Социология. Этнология. — 2003.— № 2.— C. 3-45.

3. Рассказов Л.П. Законодательное развитие института земельной собственности в Российской империи второй половины XIX — начала XX века / Л.П. Рассказов, Д.А. Верхогляд // Право и государство: теория и практика.— 2013.— № 11.— С. 83-87.

4. Рахманов А. Особенности легитимности частной собственности в православии / А. Рахманов // Социология: теория, методы, маркетинг. 2010.№ 4. - C. 101-113.

5. Соколов Д.В. 0 проблеме классификации частной трудовой собственности / Д.В. Соколов, Н.С. Блинова // Вестник Российского университета кооперации. - 2016. 一 № 2(24). - С. 49-52.

6. Солодова Г.С. Некоторые воззрения христианства: собственность, богатство и бедность / Г.С. Солодова // ЭК0. — 2006. № 1 (379). — С. 161-178.

7. Сюкияйнен Л. Мусульманское право собственности: юридическое осмысление религиозных постулатов / Л. Сюкияйнен // Отечественные записки. 2004.— № 6.— URL: https://strana-0z.ru/2004/6 (дата обращения 04.04.2021)

( С Соколов Дмитрий Викторович ( sokolov77@inbox.ru ), Александров Михаил Вячеславович ( amv-ekf@yandex.ru ). Журнал «Современная наука: актуальные проблемы теории и практики» 